\title{
Basic and applied aspects of the genetic analysis of the ym4 virus resistance locus in barley
}

\author{
E Bauer, A Graner * \\ Federal Centre for Breeding Research on Cultivated Plants, Institute for Resistance Genetics, D-85461 Grünbach, Germany
}

(Received 15 May 1995; accepted 4 July 1995)

\begin{abstract}
Summary - The barley mosaic virus complex has become one of the major pathogens of cultivated winter barley in central Europe. One resistance gene (ym4) mediates complete immunity against barley mild mosaic virus (BaMMV) and barley yellow mosaic virus type 1 (BaYMV-1). An attempt is made to molecularly characterize the $y m 4$ resistance locus on the long arm of barley chromosome 3 by means of RFLP and sequence-tagged-site (STS) markers. Two closely linked molecular markers have been identified which are suitable for marker-assisted selection for the resistance gene. A high resolution mapping population is being developed in order to provide the basis for positional cloning of the ym4 resistance gene.
\end{abstract}

barley / BaMMV / BaYMV / disease resistance / RFLP marker

Résumé - Aspects fondamentaux et appliqués de l'analyse génétique de la résistance au virus liée au locus ym4 chez l'orge. Le complexe viral des mosaïques des orges est devenu un des pathogènes majeurs de l'orge d'hiver en Europe centrale. Un gène de résistance (ym4) confère une immunité complète au virus de la mosaïque modérée de l'orge (BaMMV) et au virus type 1 de la mosaïque jaune de l'orge (BaYMV-1). On essaie de caractériser moléculairement le locus de résistance sur le bras long du chromosome 3 de l'orge au moyen de la RFLP et de marqueurs à séquence étiquettée (STS). Deux marqueurs liés à courte distance ont été identifiés qui conviennent pour une sélection assistée par marqueurs pour le gène de résistance. Une carte à haute résolution est en cours de développement pour fournir la base du clonage de position du gène de résistance ym4.

orge / virus de la mosaïque modérée de l'orge / virus de la mosaïque jaune de l'orge / résistance au virus / RFLP

\section{INTRODUCTION}

In the last decade the barley yellow mosaic virus complex became a serious threat to the cultivation of winter barley in central Europe. Up to now, 3 virus strains have been observed: (1) barley mild mosaic virus (BaMMV); (2) barley yellow mosaic virus type 1 (BaYMV-1); and (3) barley yellow mosaic virus type 2 (BaYMV-2). Although there are several classes of resistance against one or more virus strains (Graner et al, 1995), the resistance of almost all cultivars rests on a single recessive gene, which confers complete immunity against BaMMV and BaYMV-1. This

\footnotetext{
* Correspondence and reprints
} 
ym4 gene has been located on the long arm of barley chromosome 3 by means of telotrisomic analysis (Kaiser and Friedt, 1992) and, later, by the aid of RFLP markers (Graner and Bauer, 1993) to the distal portion of this chromosome arm. Two tightly linked RFLP markers (MWG010 and MWG838) have been identified, providing the basis (1) for marker-assisted selection in resistance breeding programmes and (2) for a high resolution mapping strategy around the $y m 4$ locus, which, in turn, is a prerequisite for a mapbased cloning approach. In this paper we report the conversion of a linked RFLP marker into a sequence-tagged-site (STS) marker, which renders more practicable marker-assisted selection for this gene. The usefulness of the above-mentioned mapping strategy for the genetic resolution of the complex virus resistance gene cluster on chromosome 3 is also discussed.

\section{MATERIALS AND METHODS}

\section{Molecular and linkage analysis}

DNA extraction, digestion and hybridization were carried out as described previously (Graner et al, 1991). Linkage analysis was conducted using Mapmaker computer software (Lander et al, 1987). Crossover units were converted into map distances (cM, centiMorgan) by applying the Kosambi function (Kosambi, 1944). PCR conditions for primer-pair MWG838 were as follows: $20 \mathrm{ng}$ of genomic DNA were amplified in a $20 \mu \mathrm{l}$ reaction mixture (final concentrations: $100 \mu \mathrm{M}$ each dNTP, $200 \mu \mathrm{M}$ of forward and reverse primer, $1 \times$ reaction buffer, 0.5 units Taq DNA polymerase (Pharmacia)). An initial denaturation step of $3 \mathrm{~min}$ at $94^{\circ} \mathrm{C}$ was followed by 30 cycles of $1 \mathrm{~min}$ at $94^{\circ} \mathrm{C}, 1 \mathrm{~min}$ at $53^{\circ} \mathrm{C}, 2 \mathrm{~min}$ at $72^{\circ} \mathrm{C}$ with a final extension step of $5 \mathrm{~min}$ at $72^{\circ} \mathrm{C}$.

\section{Plant material and resistance tests}

Genetic data are based (1) on a progeny consisting of $287 F_{1}$ anther derived doubled haploid lines from a cross between cv Igri (susceptible) x cV Franka (resistant) and (2) on a segregating $F_{2}$ population of the same cross comprising 384 plants. Resistance testing in the $\mathrm{DH}$-population was performed by mechanical inocculation with BaMMV according to Friedt (1983) in 2 replications comprising 5 plants each. Presence or absence of BaMMV was examined by ELISA using antibodies kindly supplied by $\mathrm{Dr} W$ Huth (Braunschweig, Germany).

\section{RESULTS}

\section{Localization of the ym4 locus}

In order to confirm the exact map position of the $y m 4$ gene between the 2 flanking RFLP markers MWG010 and MWG838 in the telomeric region of barley chromosome 3L (Graner and Bauer, 1993), linkage analysis was carried out in a $\mathrm{DH}$ population consisting of 287 lines. Figure 1 shows the distal portion of the long arm of chromosome 3 with 6 linked RFLP markers.

\section{RFLP analysis of the ym4 locus}

Marker MWG010 exhibits the closest linkage $(0.9 \mathrm{cM})$ to the $y m 4$ gene. This probe shows a very clear RFLP pattern, which proved to be useful for the discrimination of barley cultivars with and without the ym4 gene, respectively (Graner and Bauer, 1993). Resistant cultivars display a common $1.8 \mathrm{~kb} \mathrm{Bam} \mathrm{HI}$ fragment, while susceptible cultivars share a $2.1 \mathrm{~kb}$ fragment. In the next step, the conversion of linked RFLP probes into STS markers was attempted, allowing a PCRbased identification of resistant/susceptible plants. Sequence analysis of marker MWG838 led to a STS primer-pair amplifying a $900 \mathrm{bp}$ fragment. Two frequently cutting restriction enzymes (Hin $\mathrm{fl}$ and Rsa I) were identified, which tag point mutations within the amplified fragment. Both

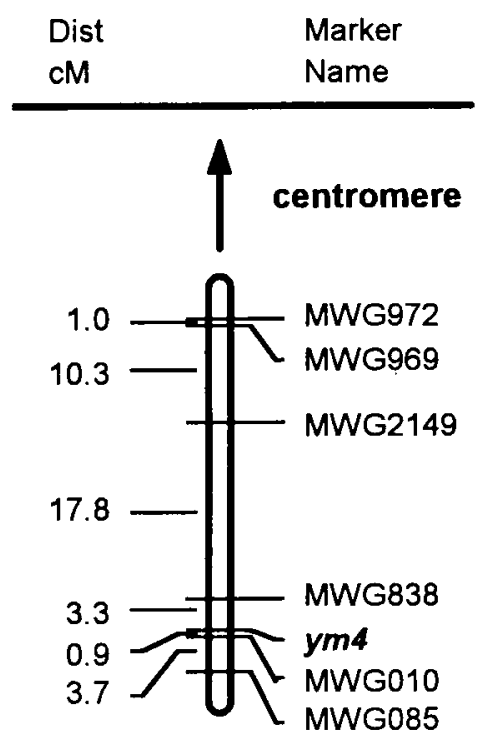

Fig 1. Partial RFLP map of chromosome $3 \mathrm{~L}$ including the $y m 4$ resistance gene based on the analysis of $287 \mathrm{DH}$ lines. Map distances are given in $\mathrm{cM}$. 
enzymes identify the same locus and show a easy-to-score codominant banding pattern, which is identical to the corresponding RFLP pattern of probe MWG838 and therefore can be used for differentiation of resistant and susceptible genotypes (fig 2).

\section{Development of a high resolution mapping population}

In order to provide the basis for a map-based cloning approach, a strategy for high resolution mapping around the $y m 4$ locus was devised. Upon analysis of $1000 \mathrm{~F}_{2}$ individuals, a genetic resolution of $0.05 \mathrm{cM}$ will be obtained. In order to keep the number of resistance tests as small as possible, molecular markers, which flank the ym4 gene are being used for RFLP analysis of the entire progeny. However, only those plants which carry a recombination in the corresponding interval will be of use for the construction of a high resolution map around the gene. All of the remaining plants will be discarded (fig 3 ). This approach eliminates resistance testing on a single-plant level, since, after a subsequent selfing step, homozygous recombinants can be identified and subjected to a phenotypic analysis. Preliminary results of the first selection cycle are based on the analysis of $384 \mathrm{~F}_{2}$ plants. Map distances between markers MWG838, MWG010 and the Est1 isoenzyme locus have been computed and are in good accordance with data from the $\mathrm{DH}$-population. The position of the $y m 4$ gene will be determined after analyzing the selfed recombinants. In comparison to the corresponding map region of the $\mathrm{DH}$-population, a slight

DH-progeny

$M P_{s} P_{r} \overline{s s r r r s s s r r s s}$ s

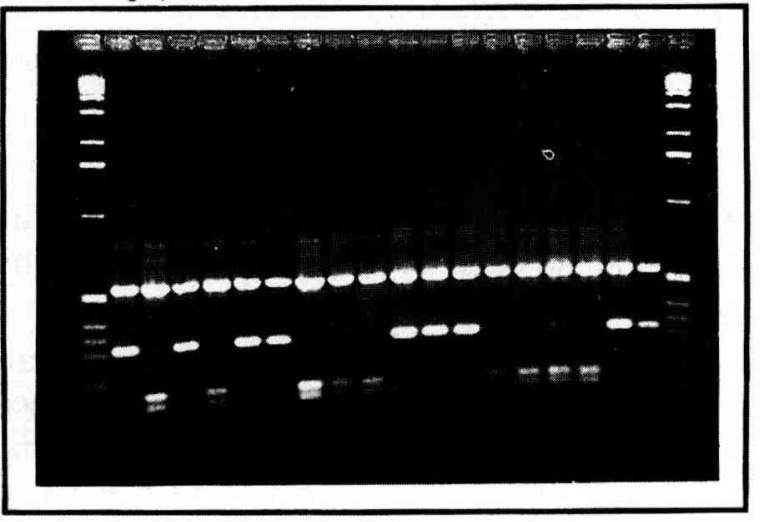

Fig 2. $1.5 \%$ agarose gel containg $H i n$ fl digested amplification products of STS primer-pair MWG838. $\mathrm{P}_{\mathrm{S}}$ : susceptible parent, $P_{r}$ : resistant parent, $s$ and $r$ : resistance reaction (susceptible or resistant) of DH-progeny, M: size marker. increase of the genetic distance between MWG838 and MWG010 is visible (5.5 versus 4.2 $\mathrm{cM})$, but it is still within the limits of the corresponding standard deviation.

\section{DISCUSSION}

In practical breeding programmes for resistance to BaMMV/BaYMV-1 virus the above-described molecular markers provide a good tool for markerassisted selection, thus offering the possibility of avoiding time-consuming resistance testing in infected fields or in the greenhouse. Our efforts are concentrated on the conversion of RFLP probes, which still require the use of radioisotopes, into a PCR-based user-friendly STS marker system. Up to now, the conversion of RFLP probe MWG010 has not been effective, probably due to the fact that this probe has a very small insert size (280 bp), which reduces the probability to tag point mutations within the amplified sequence. Another problem is the fact that this probe detects more than one locus. On the other hand, marker MWG838 is an example of a successful conversion into a robust primer system. In comparison to the RAPD marker system, the banding pattern is easier to score and because of the use of 20 mer primers, the amplification can be performed under stringent conditions. However, enzymatic digestion is necessary after amplification. One major advantage of STS markers is that they are usually codominantly inherited like RFLP markers, in contrast to normal dominantly inherited RAPD markers, therefore providing a maximum of genetic information.

In an attempt to isolate the ym4 gene by positional cloning, a high resolution map based on $1000 \mathrm{~F}_{2}$ plants is being constructed around this locus with a maximal genetic resolution of 0.05 $\mathrm{cM}$. The analysis of large numbers of progeny plants is necessary to verify the flanking position of the 2 markers, which, in turn, is a prerequisite for the successful screening of large-insert YAC (yeast artificial chromosome) libraries. The above-described marker-assisted strategy for the construction of a high resolution mapping population renders possible the identification of recombinant lines for the map interval between MWG838 and MWG010. These recombinant lines are genetically equivalent to recombinant inbred lines, allowing repeated resistance testing, which is essential in order to achieve the required accuracy for the map-based cloning approach. Thus, the high resolution mapping population 


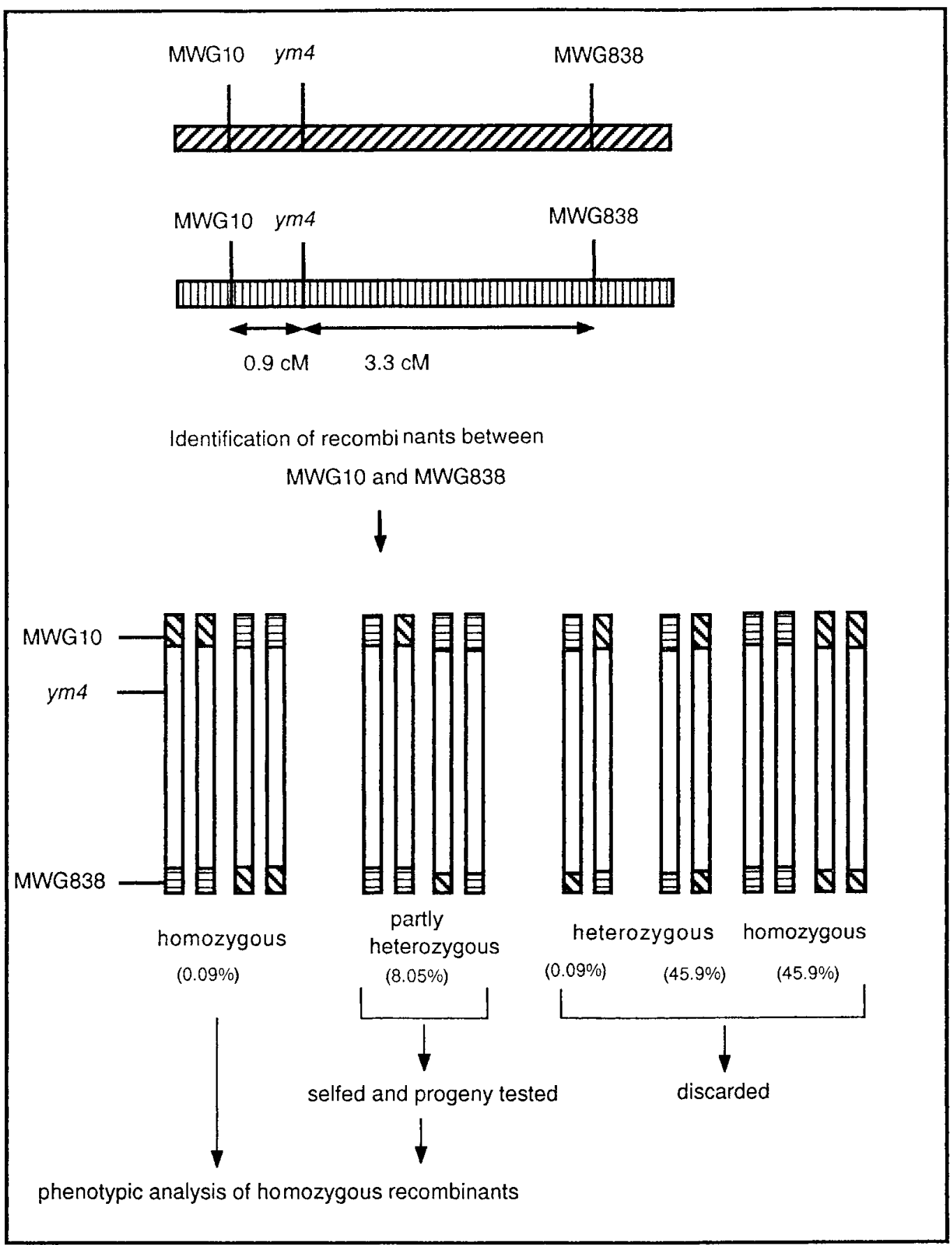

Fig 3. High resolution mapping strategy based on 2 flanking markers (MWG010 and MWG838), spanning an interval of $4.2 \mathrm{cM}$ around the $y m 4$ gene.

should provide the basis for bridging the gap between genetic and physical distances. Given a genome size in barley of ca $5.2 \times 10^{9} \mathrm{bp}$ and a total map distance of ca $1500 \mathrm{cM}, 1 \mathrm{cM}$ equals about $3.5 \times 10^{6} \mathrm{bp}$. This means that a genetic resolution of the map around the $y m 4$ locus below $0.1 \mathrm{cM}$ is necessary, if we consider that in the existing barley YAC library most of the inserts are between 100 and $200 \mathrm{~kb}$ (Kleine et al, 1993). However, it has been observed recently that in telomeric regions the ratio between genetic and physical distances is more favourable, thus increasing the odds for map-based cloning of the ym4 locus (Sorokin et al, 1994).

Obviously it is desirable to find additional markers, which show closer linkage to the resistance gene in order to maximize the chance of finding one single YAC clone containing both flanking markers and thus, presumably also the resistance gene. By using the recombinant lines which are homozygous in the region of interest it should be possible to identify closely linked markers, eg, 
RAPD markers as was shown for the $y m 4$ locus by Ordon et al (1995).

Another aspect of the above-described high resolution mapping strategy is its usefulness for the genetic analysis of complex virus resistance gene clusters, eg, the $y m 4$ and $y m 5$ virus resistance genes on chromosome 3L (Graner et al, 1995). Here, the progeny of a cross between carriers of different resistance genes plants carrying recombinations between the 2 resistance loci can be identified by the use of flanking markers as has been described for the high resolution mapping population. Since only these plants are informative for the genetic resolution of the gene cluster resistance, testing can be reduced to a minimum. By following this strategy, the accurate determination of the map position and map distance between these 2 genes should become feasible.

\section{REFERENCES}

Friedt W (1983) Mechanical transmission of soil-borne barley yellow mosaic virus. Phytopath Z 106, 16-22

Graner A, Jahoor A, Schondelmaier J et al (1991) Construction of an RFLP map in barley. Theor Appl Genet 83, 250-256
Graner A, Bauer E (1993) RFLP mapping of the ym4 virus resistance gene in barley. Theor Appl Genet 86, 869-893

Graner A, Bauer E, Kellermann A, Proeseler G, Wenzel G, Ordon F (1995) RFLP analysis of resistance to the barley yellow mosaic virus complex. agronomie 15, 475-480

Kaiser R, Friedt W (1992) Gene for resistance to barley mild mosaic virus in German winter-barley located on chromosome 3L. Plant Breed 108, 169-172

Kleine M, Michalek W, Graner A, Hermann RG, Jung C (1993) Construction of a barley (Hordeum vulgare L) YAC library and isolation of a Hor1-specific clone. Mol Gen Genet 240, 265-272

Kosambi DD (1944) The estimation of map distances from recombination values. Ann Eugen 12, 172175

Lander ES, Green P, Abrahamson et al (1987) MAP. MAKER: an interactive computer package for constructing primary genetic linkage maps of experimental and natural populations. Genomics 1, 174-181

Ordon F, Bauer E, Friedt W, Graner A (1995) Markerbased selection for the $y m 4$ BaMMV-resistance gene in barley using RAPDs. agronomie 15, 481485

Sorokin A, Marthe F, Houben A, Pich U (1994) Polymerase chain reaction mediated localization of RFLP clones to microisolated translocation chromosomes of barley. Genome 37, 550-555 